21. Pexrological Notes on Rocks from Southern Abrssinia, collected by Dr. Reginald Koetrlitz. By Catherine A. RaIsin, D.Sc. Lond. (Communicated by Prof. T. G. Bonney, D.Se., LL.D., F.R.S., F.G.S. Read March 11th, 1903.)

\title{
[Plate XXI-Map.]
}

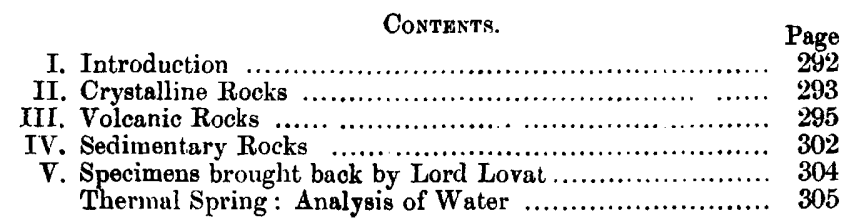

\section{Introduction.}

AN interesting account of a journey into Southern Abyssinia was given in the Journal of the Royal Geographical Society for 1900, by Mr. H. Weld Blundell.' He followed a route roughly westward from Berbera through Somaliland and Southern Abyssinia, then turned northward to the Blue Nile and into the Sudan. On this expedition Dr. R. Kottlitz collected a large number of rock-specimens which (at the kind suggestion of Mr. Teall), together with some obtained by Lord Lovat, were entrusted to me for description." The absence of the former on the Antarctic Expedition makes it impossible to submit these notes to him for revision. But the following brief statement is condensed from a topographical sketch which he posted to me from the ship Discovery at Lyttelton (New Zealand) in the spring of 1902, and a more general account by him will be found printed as an appendix to Mr. Blundell's paper mentioned above. A map of the route was published with that paper, from which I have copied the spelling for the placenames, where possible. I have identified a few other localities on the British War Office map of the district, but the remainder had to be taken from the rough pencil-labels.

The expedition crossed the coastal plain from Berbera, passing knoll-like isolated bills, the road gradually rising to the edge of the plateau, where the shattered rocky ground often exposed schistose and granitic masses. Orerlying these, sedimentary beds and volcanic rocks were seen in places, and occasionally flat-topped basaltic hills occur. In the great volcanic district of Southern Abyssinia, sheets of basalt are often exposed, sometimes vesicular and scoriaceous, especially at the surface of the flows, sometimes exhibiting columnar structure. On the Hawash Plain, many hills are more or less complete volcanic cones, with the craters preserved.

1 Geogr. Journ. vol. xr (1900) p. 97.

2 Unavoidable delays occurred in the transmission of some of the collections, so that these notes appear somewhat late. 
One of these, extinct, but perfect in form, 40 miles south of Addis Abbeba, is Mount Saquala, from which specimens of rocks have been brought. Farther west, beyond the Didesa River, older rock in places underlies basalts or similar volcanic deposits, but the main mass of the mountains is composed of disturbed and contorted schistose and granitic rocks.

The collection contains some specimens of structural interest, and further illustrates certain petrological features which we may perhaps associate with East African geology. Thus the presence of some pressure-modified Archæan rocks at certain zones, the abundance of volcanic masses, and the occurrence among these of soda-bearing types, will be gathered from the following account.

\section{Crystaluine Rocks.}

I have grouped the granites and diorites with the gneisses and schists, as some specimens exhibit transitional characters. These rocks occurred mainly in two areas-one, south-west of Berbera; the other around the head-waters of the tributaries of the Blue Nile. At both localities the Archæan rocks seem to have been thrust up, and some of the specimens are crushed. Westward of the range bounding the coastal plain, they form a floor largely covered by overlying sandstones, limestones, and volcanic rocks of later epochs. According to Dr. Koettlitz, they often exhibit a high dip with contortions and foldings.

\section{(1) Granites.}

The granites, both coarse- and fine-grained, some with porphyritic crystals, consist of quartz, felspar (often plagioclase or microcline), biotite, and occasionally apatite or zircon. In crystals formed of a micropegmatitic growth of two felspars, the alternate, roughlyparallel, irregular streaks are generally plagioclase or microcline. A grey granite with black biotite (from between Dabus and Jem Jem) encloses patches ( 2 inches or more across) of a close-grained blackish hornblende-schist or fluxion-diorite, as if one magma, and it is doubtful which, had intruded into the other.

Probably a dyke or vein is represented by a specimen from the same place, of a rather modified microcrystalline garnet-aplite. The felspar shows evidence of strain in its wavy cleavage-planes; and aggregates of white mica are doubtless derived from an original constituent, the residuum of which may have formed the small associated garnets. Other indications of pressure are found in some granites, although the most marked are in certain gneisses.

\section{(2) Gneisses.}

Some are normal, but many are pressure-modified, and certain of these are finely speckled (the 'pepper-and-salt' type). One hornblende-gneiss allied to a diabase, crushed and reconstituted, and other much modified specimens come from near Jibuli (Gibeli), 
where the rocks were 'much tilted' and re-appeared 'again and again' on the journey. One of these, pale yellowish-grey with silvery surfaces, consists of lenticles of quartz-felspar mosaic, with white and pale brown mica along streaks or zigzag lines. In a much-crushed rock, from the same locality, the mosaic forming pinkish streaks contains coarse patches with mica- or chlorite-flakes, and crystals of felspar (orthoclase and plagioclase) much corroded. In another granitic rock the narrow red felspathic bands (bounded by lines of biotite) consist of a mosaic, either fine-grained, containing iron-oxide and some biotite, or coarse-grained with microcline, white mica, and a streak of a secondary mineral, possibly a zeolite. The rock probably owes its structure to fluxion-movements, and resembles marginal specirinens from a Vosges granite, the structure of which I incline to attribute to this cause. (A gneiss from Gumbi, towards the Nile Valley, weathering red, has a granular matrix with streaky biotite and may be similar.) Another rock from near Jibuli, from the river-bed, is reddish, banded, compact and hälleflintoid, not unlike a rhyolite; but the constituent grains of the mosaic are often angular and clearly defined, so that (like some of the preceding specimens) it is probably a crushed and recrystallized gneiss, somewhat similar to certain Saxon granulites.

I pale-grey, medium-grained, holocrystalline rock, from the top of a steep hill on the road from Mendi to Gumbi (Gimbi), is composed of plagioclase-felspar and quartz, with ragged flakes of biotite, clear epidote, and some sphene.

\section{(3) Hornblende-Schists and Foliated Diorites}

are all blackish fine-grained rocks, containing plagioclase, biotite, hornblende, iron-oxide, with sometimes augite, and occasionally a zircon. One specimen, from north-west of Quattie Camp towards the Blue Nile Valley, is ophitic; but the structure in the rocks generally is granular and often fluxional, as in one south-west of Berbera, and in one towards Fyambiro, while two others exhibit a slightly-brecciated appearance. A schist from between the Dabus River and Jem Jem is undoubtedly crushed, traversed by narrow prisms of hornblende with a parallel arrangement. In another schistose rock from Gumbi(one specimen of it coming from the summit of the hill) bright brick-red and brown patches are present. These are rich in narrow prisms of (possibly) an iron-stained epidote, while the wavy bands of mosaic in the slice contain some iron-oxide. Small micaceous or kaolinized aggregates have been formed probably from felspar-crystals. The rock may be a much-crushed ferriferous diorite.

\section{(4) Diabase; Hornblendic Gabbro ; Pyroxenite.}

These rocks all come from the South-west of Abyssinia, from localities where some granitic or dioritic rocks occur. A specimen from Gumbi exhibits green hornblende with patches of epidote and 
(?) zoisite, within a mosaic in which the orientation is partly due to pressure. In another rock from beyoud Jem Jem (containing a carbonate), the hornblende is ragged and fibrous at the ends, and, like the biotite, has undergone alteration, but whether by pressure is less certain in this example. Two rocks in the hand-specimens are like a typical gabbro. One, fairly coarse (from Govie, where the rock is said to extend for several miles, and from Gauti), is composed of felspar mostly fresh (probably labradorite), of dark-green, wellcleaved hornblende resembling altered diallage (often enclosing felspar), with epidote, apatite, and iron-oxide. The other (from the Didesa River), consisting of kaolinized felspar and of a platy green hornblende, partly recrystallized or aggregate, occurs in a junctionspecimen with a speckled diabase (both containing epidote), but the passage is somewhat gradual, as if either they were parts of one mass, or the intruding diabase had carried off pieces of the gabbro.

A dark-greenish rock from the top of the hill between Donkoro and Bojji, resembles a picrite, with its large platy crystals ( $\frac{1}{2} \mathrm{inch}$ long) lustre-mottled. These are found to consist of green pleochroic hornblende, sometimes paler at the exterior. 'They enclose grains of a well-cleaved white augite, often brown-stained at the edges, which resembles that described by Prof. Bonney in the 'picrite' of Porthlisky, where olivine is also present.' In parts of this Abyssinian slice, the augite is intergrown with the hornblende as a granular aggregate, or in an almost micro-ophitic arrangement; and in places the augite is changing to hornblende, that is, the rock is a form of hornblende-pyroxenite.

\section{Volcanic Rochs.}

The collection includes a large number of volcanic rocks, most of them from Southern Abyssinia. The great majority are basalts and andesites, but phonolites or allied rocks occur, with one loose specimen of obsidian and some tuffs.

\section{(1) Basalts.}

(i) Olivine-basalt.-A blackish rock from the basaltic region between Gudr and Toki is compact, but crowded with large crystals, sometimes half an inch long. These are of augite or of olivine, the latter often a transparent peridote, but sometimes possibly fayalite. One specimen of the rock, with more groundmass, contains small whitish amygdales and lath-shaped felspar-microliths. In the olivine in another slice, curved cracks in one crystal slightly resemble perlitic spheroids within cross-jointed blocks, and the glassy magma extends along some cracks. The augite is brownish with a puce-coloured edge, and encloses some olivine. The groundmass is colourless, partly glassy, but includes felspar, and contains small

1 Quart. Journ. Geol. Soc. vol. xii (1885) p. 519 \& pl. xvi, fig. 5. The colourless augite is more or less distinct in the boulders from Anglesey, $i b i d$. 1. 518. 
crowded crystals of augite and of iron-oxide. The specifio gravity of three specimens (tested by a Walker's balance) is respectively $2 \cdot 95$, $3.09,3 \cdot 18$, which is higher than that of an ordinary tachylyte $(2 \cdot 71$ to $2 \cdot 86)$. Thus, notwithstanding the presence of felspar (which, as Prof. Bonney has shown, is always potential and sometimes actual in the rock from Limburg itself ${ }^{1}$ ), the specimens really belong to the limburgites.

Olivine is a distinct constituent, although not abundant in a few other basalts, which often have a purplish tinge, and resemble the Niedermendig and allied rocks. The two most typical come from the Saquala district. One from the hillside between that mountain and Galanda Lotha is minutely microcrystalline, and contains larger crystals of augite and plagioclase, with a ferruginous olivine. 'This is bright brown, with metallic iridescence, in the hand-specimen; and under the microscope it resembles the brown-edged crystal changing to iron-peroxide figured by A. Rosiwal. ${ }^{2}$ Several felsparcrystals have undergone partial melting-down, forming an outer cloudy or gelatinous-looking part, in which the iron-oxide has been deposited along the plagioclase-bands, by intiltration from the groundmass. A specimen from Tsingari is similar, but it contains more plagioclase, is more coarsely crystalline, and is lighter in colour than an ordinary basalt.

(ii) Basalts proper.-These are mostly microcrystalline, but in a few a little residual glass may occur. Several contain some ferruginous olivine, and occasionally plagioclase with a cloudy appearance, or granular patches caused by a melting-down of small crystals. Among these basalts from Somaliland aro a purplish vesicular rock from the river-bed at Hamas, a specimen from near Addi Adeya from a talus (but 'tiers of rock probably similar appear above'), and one from the Hill of Sobolo ( 5854 feet), where a 'chalk-like rock fills the interstices.' ${ }^{3}$ Several microcrystalline basalts come from near Jigjiga, one perhaps rather to the east, but two in situ, one 'from apparently a small intrusive sill' in the pass, and another with sandstones or grits ' on the road to Fantalli and Harrar.' Also associated with grits was a basalt from the hill close to the east side of the camp at Garsa (Karsa). Similar rocks were taken 'from a dyke in the valley west of Colluby,' where the expedition camped, and from the pass high up before getting to camp, and some distance west at the Laga-Hardim Camp, both in the lower and the upper series of rocks. Basalts were collected from the second brookcutting going from camp into Addis Abbeba, from between that town and Akaki ('exposed among softer tuff-rock'), and in situ at Galanda Lotha towards Mount Saquala.

A slice cut from a dark-grey finely-speckled basalt from Tsingari contains a few microporphyritic felspars, partly corroded and

1 Geol. Mag. 1901, p. 411.

2 'Beiträge zur' geol. Kenntniss des östlichen Afrika' pt. ii, Denkschr. d. $k$. Akad. Wissensch. Wien, vol. lviii (1891) pl. ii, fig. 4.

${ }^{3}$ See p. 303. 
exhibiting rather micropegmatitic inclusions, and one interesting crystal of augite. It is large ( $\frac{3}{10}$ inch long), irregular at the edge as if corroded, and encloses numerous clear, small grains of augite like a micropegmatite, in the arrangement of which a slight orientation along what may be cleavage-planes can be traced. The explanation is difficult, but, although local melting and recrystallization seem possible, it is perhaps more likely that, after the small augites had formed, the large crystal developed around them, spreading until solidification of the neighbouring groundmass prevented further growth and produced an irregular outline.

In a dark slaty-grey basalt from Chellahah the groundmass contains a little glass, and microlithic felspars exhibiting a fluxional arrangement. The rock from a hill near Mendi is compact, subophitic, but with small amygdales.

(iii) Glassy basalts include a pebble from a brook towards Errer, one specimen from near Hirna (although this might be a basic andesite), others from the hill east of Laga-Hardim Camp (including one or two from the upper series), from Fantalli, from the surface between Akaki and Addis Abbeba, and from Gatama. These rocks are mostly blackish, compact or finely glittering. The siena-brown glass contains imperfect skeleton-crystals and granules of opacite which render the matrix confusedly dusky. It encloses greenish palagonitic patches and some small crystals. Two or three specimens are purplish, and some vesicular, others containing porphyritic crystals.

(iv) Vesicular or scoriaceous rocks (doubtless basalts).-.. The most scoriaceous arc from the talus near Addi Adeya, the greatest number from the hill east of the camp at Laga Hardim, many from the upper series of rocks. Two others are from near the Hawash River, two from Fantalli, and one from Toki.

\section{(2) Phonolites and Allied Rocks.}

Rocks containing nepheline occur at two localities. ${ }^{1}$ They are found at Garsa, about long. $42^{\circ}$ E., beyond Lake Haramaia in the South-East of Abyssinia, with sandstones and grits, and near Bilo (about long. $37^{\circ} \mathrm{E}$.), much farther west on the Gibbe River, connected with the extensive area of Southern Abyssinia which is occupied almost wholly by volcanic rocks. The Saquala rocks, from south of Addis Abbeba, are probably allied to the phonolites.

Two specimens of a blackish, almost glassy-looking rock from Bilo (or near that place), weathered brown, contain large ( $\frac{1}{2}$-inch) cleaved glassy crystals. These sometimes are singly twinned, with two cleavages at about right angles, sparsely cracked, extinguish straight, have low double refraction, and probably are sanidine; although a possible twinning like that of anorthoclase is very faintly

1 Compare also A. Rosiwal, 'Beitr. geol. Kennt. des östl. Afr.' pt. ii, Denkschr. k. Akad. Wissensch. Wien, vol. Iviii (1891) p. 465; J. W. Gregory, Quart. Journ. Geol. Soc. vol. lvi (1900) p. 205 ; \& G. T. Prior, Min. Mag. vol. xii (1900) p. 255.

Q.J.G.S. No. 234. 
represented in one or two crystals. One or two others, rounded in outline, apparently without cleavage, containing minute Huid enclosures, exhibit an all-round extinction. This suggested the possibility of leucite, but the characteristic structure is wanting, and the grains might be transverse sections of a hexagonal crystal like nepheline. 'The porphyritic crystals sometimes enclose grains of augite or patches of the groundmass. 'T'he groundmass is micro-ophitic, perhaps with a little residual glass, with lath-shaped filspars often singly twinned, and nepheline in rectangular and hexagonal sections. A pale filmy hornblende exhibits characteristic cleavage, especially well shown in one crystal. The pleochroism in this (and in one or two which extinguish at about $40^{\circ}$, and enclose opaque blackish grains) is from pale chestuut or reddish-brown to very pale fawn-colour. In other (mostly minute) crystals, often extinguishing at $18^{\circ}$ or $20^{\circ}$, it is from chestnut-browu to pale apple-green. The hornblende may be a common species, but it exhibits a resemblance to the catophorite of Brogger from Grussletten.' Dark-brown or red-brown crystals, often opaque in the centre, are possibly cossyrite." Another mineral, having a peculiar pleochroism to a deep greenish-blue, often occurs in a small patch clustered around nepheline or felspar, and although perhaps not the most typical example, is doubtless riebeckite, ${ }^{3}$ jossibly with some agirine, and the slice contains a pale-groen augitc.

A rock obtained just before reaching Bilo, dark-grey, with a somewhat greasy lustre, shows a slight linear streaking. The small, crowded, colourless crystals in the groundmass are mostly nepheline, exhibiting hexagonal and rectangular sections. Some microchemical tests gavo further corroboration of the identification of this mineral. The rock-slice was readily etched by hydrochloric acid (in $1 \frac{1}{2}$ minutes), and stained with malachite-green. The solution in hydrochloric acid deposited many small cubes of sodiumchloride, and in hydrofluosilicic acid, good erystals of sodium-fluosilicate. Lath-shuped felspars, less sharply defined, and a small pyroxene occur, resembling minerals found in the next-described rock. Pale-brown films, sometimes hexagonal, with aggregate polarization, are possibly mica.

A speckled greyish rock from Bilo exhibits close wary shimmering surfaces. In the microscope-slice, two generations of felsparcrystals occur, both numerous, distinctly orientated, probably sanidine and anorthoclase, the latter often exhibiting an undulose extinction, both in this and in the preceding rock. Some of the

${ }^{1}$ See 'Die Eruptivgesteine des Kristianiagebietes: I. Die Gesteine der' Grorudit-'Linguait Serie,' Vidensk. Skrift. 1894, No. 4, pp. 27-39; and Rosenbusch [transl. Iddings] 'Microscop. Physiogr:' 4th ed. (1898) App. p. $352 c$.

${ }_{2}$ This identitication was suggested by Mr. G. I. Prior. I have to thank Mr. L. Fletcher for kind permission to study slices in the collection at the British Museum (Natural ITistory). I owo many thanks to Mr. Prior for selecting some of these, for looking at my slides, and for giving me on several a confirmatory opinion.

${ }^{3}$ I have to thank Prot. Bonney for the loin of slides in which $I$ was able to study typical riebeckite, some in the Mynydl-Mawr rock, and a still richer development in a Socotra specimen. 
larger crystals, rather scattered, not quite complete in outline, exhibit straight or all-round extinction, and are probably nepheline. In some of these a narrow irregular margin around the enclosed crystal is a secondary product formed of an isotropic mineral, probably sodalite. ${ }^{1}$ The pyroxene which fits in between the other constituents, and sometimes fringes the nepheline, is mainly ægirine or an ægirine-augite. As in the last rock, much of this is somewhat platy, with extinetion about $30^{\circ}$, pleochroic from green to brownish with the usual tints, and rather resembles ægirine-augite. Ironoxide is present, and one felspar encloses a fow very minute zireons. A microscopic vein is partly filled with what is possibly aragonite. The rock is a phonolite with fluxional structure, and somewhat resembles the sölvsbergite from Edda Gijorgis (Central Abyssinia) brought by Dr. Sadebeck."

Among the 'rocks with a dip of $80^{\circ}$ to the north-east, obtained in ascending the hill close to the east side of the camp at Garsa,' partly grits and sandstones, are pale fawn-coloured or whitish felsitic-looking rocks with blackish speckled patches. The groundmass (which possibly includes nepheline) passes at places into a micropegmatitic intergrowth with a greenish or brownish mineral forming moss-like groups. The greenish mineral includes riebeckite (pleochroic from deep blue to greenish and pale yellow, with wellmarked cleavage and low extinction), and associated with this some ægirine (pleochroic from grass-green to greenish-yellow, with low extinction-angle and strong double refraction). The brown mineral, although it may partly represent a cossyrite, is, much of it, doubtless an alteration-product, and iron-oxide and small epidote are present. Microporphyritic, generally oblong, erystals occur, from the edge of which radial tufts grow inward, certainly a secondary developmont, possibly due to subsequent heating by intrusion of an igneous magma. The crystals sometimes extinguish straight, and, although the secondary replacement renders the identification of many uncertain, some at least are probably nepheline; and the rock was readily etched with hydrochloric acid, especially the microporphyritic crystals, and these most strongly along the margin. Also, with hydrofluosilieic acid, minute hexagonal crystals of sodiumfluosilicate were formed in fair quantities. ${ }^{3}$ The rock somewhat resembles an ægirine-tinguaite from Hot Springs (Arkansas), a slice of which is in the collection at the British Museum (Natural History).

The rocks next described, although apparently not containing nepheline, are certainly allied to the phonolites.

Mount Saquala and its neighbourhood.-A dark-grey rock in two specimens from this mountain, contains small porphyritic crystals of felspar (sanidine and anorthoclase). Other microporphyritic crystals (highly refractive, and ironstained along

1 I have to thank Prof. Bonney for the' loan of additional slides containing this mineral for comparison.

2 Described by Mr. Prior in Min. Mag. vol, xii (1900) p. 265 \& pl. iii, fig. 4.

${ }^{3}$ See Roseubusch [transl. Iddings] 4th ed. (1898) pl. $\mathbf{x}$, fig. 5. 
the edges and cracks) consist of a green, slightly-pleochroic, wellcleaved augite, and of a ycllowish mineral, probably olivine, enclosing clear belonites. The groundmass consists largely of small rectangular crystals like nepheline, but, as no hexagonal sections can be seen, they are probably orthoclase (or anorthoclase). These are embedded in a possibly quartzose base. A greenish and a brownish mincral, intercrystallized sometimes in a micro-ophitic manner, form mainly an ill-defined network with rounded meshes. The green mineral, pleochroic from bluish-green, extinguishing sometimes at $3^{\circ}$, is doubtless riebcckite, and the brown seems partly an alteration-product; but some crystals, brownish or redbrown, opaque within, and sometimes pleochroic almost to black, are very probably cossyrite. 'The rock has a likeness to some containing nepheline, and might be a soda-bearing augite-felsite or porphyrite.' 'The two specimens labelled, one from the summit, the other from the western edge of the crater, are alike, and thus afford a presumption that they represent the general character of at least part of the eruptive rock of this volcano.

Thus several types of phonolites and their allies occur in the collection. One rock from near Bilo approaches the sölvsbergite of Brœgger. A second and a third rock, from the same general locality, are rather tinguaites. One contains very abundant scattered nopheline, the other contains porphyritic felspars and riebeckite. The rock from Garsa, with moss-like patches, including rieheckite, is a possible tinguaite, and resembles the types from Adowa and Axum. Lastly, the rocks from the crater and summit of the volcanic mountain Saquala are closely allied, although containing apparently no nepheline, resembiing the 'phonolytic trachytes' described by Mr. Prior, from the 'llift-Valley' district."

A pale purplish-grey rock with close whitish bands, from Balchi Hill, resembling a porphyrite in appearance, contains porphyritic plagioclase within a minutely-microcrystalline, somewhat orientated groundmass. Although hexagonal sections are rare, some are found, and nepheline is probably present. Some very small cystals of a pyroxene occur, also iron-oxide; and a few minute crystals may represent nosean, although the lines of small black spots do not show the usual ' grating' arrangement, but are inclined to be parallel. The rock is certainly fluxional; it can only be doubtfully placed near the phonolites.

\section{(3) Andesites and Porphyrites.}

Three rocks from the bed of the Hawash River, within 2 miles of the base of Mount Saquala, westward of it, are grey and compact. The glassy groundmass shows a fluidal structure, and

\footnotetext{
1 I have to offer additional thanks to $\mathrm{Mr}$. Priol for presenting me with an advance-copy of his article on the Petrology of British East Africa, just as I had completed this paper, and allowing me to compare some of the slices described by him. The rock of Mount Suquala inuch resembles some of those classed as phonolitic trachytes or quartz-trachytes. Thus it seems allied to the earlier phonolitic lavas of the Kapte Plain, rather than to the inore basic nepheline-rocks of the active volcanoes of Doenyo $\mathrm{Ngai}$ and Mount Figon.

2 Min. Mag. vol. xiii (1903) p. 228.
} 
contains small porphyritic crystals (felspar, hornblende) and included fragments of rock like small rounded lapilli. Although these specimens appear to be fluxional andesites, they might possibly represent some of the phonolitic series.

Of two porphyrites obtained near Bilo, one, a rich red compact rock with porphyritic crystals of felspar, has a very fine-grained microlithic groundmass, coloured by iron-oxide. The second, from the hill towards Abbra Gibbe, is rather felsitic in aspect, and the groundmass is found to consist of narrow felspar-crystals with fluidal orientation. A purplish-grey porphyrite, somewhat similar, comes from east of Garsa Camp.

Several andesites occur in the hill east of Laga-Hardim Camp, in the lower series of rocks. A slice from one of these contains patches (probably due to flow-brecciation) in which a roughlyreticulate arrangement is rather like that in some nepheline-rocks, where ægirine is grouped to form the lines of the network. ${ }^{1}$

The other andesites from this locality often enclose small scoriaceous fragments and porphyritic crystals, sometimes broken or worn. They generally exbibit a fluxional structure, and one of them, from near the Hawash River, is traversed by platy jointing; another, from the Fantalli Hills, is dark, even blackish in the handspecimen.

Some pale-brown rocks from Chaffi Dunsa contain many angular fragments of crystals and of rocks, felsite or porphyrite. The groundmass consists of wavy patches rich in secondary kaolin, and of streaks of brown glass, so the rock is probably a flow-brecciated andesite, and not a tuff. Several andesites from near Addis Abbeba (the southern end) resemble those from near Laga Hardim.

Trach ytes (?).-Two rocks at the back of the Residency at Addis Abbeba are vesicular, yellow to brick-red in colour. One of them exhibiting marked fluidal structure includes green microliths and incipient crystals generally squarish in section, suggestive of a potashfelspar, as if the rock might belong to the sanidine-trachytes. The glassy groundmass of two specimens contains fragments doubtless eaught up in flowing. A specimen from Laga Hardim is compact, and of a dull olive-green. The colourless glassy base is crowded with minute granular epidote and pyroxene(?), and the fragments enclosed are of felsite, felspar, and glassy basalt. A rather earthy-looking greenish rock from the Fantalli Hills exhibits flow-structure, and contains a few fragments.

Cla y st on es.-Several claystones, probably decomposed andesites or trachytes, occurred at Addis Abbeba and at the Akaki Gorge.

Obsi di an.-A small flake of black obsidian, apparently artificially chipped, was found not far from Jigjiga (with a flake of chert and some quartz) near the place where Mr. H. W. Seton Karr obtained Palæolithic implements. ${ }^{2}$

${ }^{1}$ Compare that in the Saquala rock, p. 300.

2 Journ. Anthropol. Inst. vol. xxv (1896) p. 271. 
Pumiceous tuffs.--These are fine-grained, dusty or sandylooking rocks. Three are from east of Laga Hardim from the lower series, two from the Akaki Gorge, and two from near Bilo. In all, the powdered material consists almost wholly of colourless glasschips, generally vesicular and pumiceous, with felspathic material in one specimen.

\section{SFDimentary Rocks.}

\section{(a) Arenaceous Rocks.}

Sandstones and sands occurred between the coast and the Abyssinian frontier, and in the south-eastern part of that country. One greyish-banded quartzite, with spots coloured by homatite, collected east of Garsa, resembles rocks of a rather early geological age.

Quartzose sandstones similar to those of late Mesozoic age include one from Dobeia, not far from the coast, many at and near Jigjiga Pass, and between that frontier-pass and Chercher. In the last-named area, most of the ferruginous sandstones and grits (so characteristic of many $\Lambda$ frican collections) were obtained. In all, the quartz-grains often interlock, forming almost a quartzite, and the secondary zone along their edge is in one rock partly opalino silica. In another, lines curved like perlitic structure, or crossing at right-angles, may have been caused by heat from neighbouring volcanic masses.

The action of blown sand is sometimes exhibited, as in a loose fragment from above Hargaisa, found by Lord Lovat. This specimen of a banded, slightly calcareous sandstone is bluntly conical, but rounded, and is worn into ridges along the alternating bunds.

The compact ferruginous sandstones (almost quartzites) are purple or reddish-brown, with white felspar-speckling, banded, and often exhibit current-bedding. Infiltrating water has sometimes formed an 'iron-pan' or concretions, which in one of the coarser grits occur as rounded nodules with concentric structure.

One fine-grained red rock from near Lake Chercher, might be a rotten tuff, but is possibly only a clay.

\section{(b) Calcareous Rocks (and Organic Rocks).}

Crystalline limestone.-Two fragments of a white, coarse crystalline limestone 'from among granite... between Errer and Harrar' contain flakes, three-tenths of an inch long, of a brightbrown pleochroic phlogopite.

Dolomites. - South-west of Berbera, a whitish subcrystalline dolomite occurs at a distance of about 15 miles, and a minutely granular dolomite at about 24 miles. The latter, a 'vein in a granitoid rock,' contains angular fragments of quartz, plagioclase, green hornblende, and limestone, and a few obscure organisms. Other granular dolomites, from near the Jigjiga Pass and Fyambiro, consisting of minute rhombohedra, exhibit inclusions like those in 
the 'vein' described above, but chiefly of quartz. One of three specimens from south of Laga-Hardim Camp exhibits oolitic grains within a subcrystalline matrix. Two 'chalky-looking rocks, one not far from Addi Adeya with volcanic rocks, the other near Jummat 'with granite,' may be similar rock decomposed; and a friable specimen, effervescing briskly, and consisting of minute rhombohedra of calcite, is probably a decomposed limestone.

Brecciated or concretionary limestones. - In one brecciated-looking limestone a pale brownish matrix contains darker brown, imperfectly-rounded fragments. A marked black rim gives them a likeness to pebbles, and rounded quartz-grains or pebbles are similarly embedded. Some resemblance, however, to tufaceous or concretionary limestone suggests the action of infiltrating water. The black margin of the fragments is undoubtedly due to secondary deposition, since it extends along wavy planes in the rock and along joints or cracks. Five typical specimens have been brought, all from between Berbera and the Abyssinian frontier. One from the rock forming the hill at Dobeia, exhibits a weathered surface, coarsely grooved and pitted (? by sand-blast), and encloses small fragments of quartz and of dolomite. Of two rocks from the camp at Jefa Medr, one contains larger fragments ( $\frac{1}{2}$ to $\frac{3}{4}$ inch), the other exhibits wavy lines and narrow reins like those of septaria. In a compact rock 'protruding from the surface at many points' towards Jigjiga, are fragments of stony limestone. The margin of these is marked by concentric streaks or lines, which consist of limonite and veins of dolomite. The cracking or jointing of these limestones (along curving or rectangular lines) may be possibly due to heating by the sun's rays. Subsequently infiltration occurred, and secondary deposition generally of iron-oxide or of dolomite.

A compact limestone from the hill at Jefa Medr has apparently undergone subsequent brecciation, and may be possibly related to the above.

Limestones with organisms. - Some of the foraminiferal limestones 'about 15 miles south-west of Berbera, forming the main mass of the hill,' are compact, pinkish with whitish patches, and much dolomitized. They contain the alga Lithothamnion well preserved, and Amphistegina (?). A second type is hard, compact, whitish or drab-coloured, often breaking with subconchoidal fracture (resembling some described in 1888 also from Somaliland ${ }^{\text {) }}$. Near Jigjiga Pass this rock contains Globigerina, chambered Rotaline foraminifera, Textularia, Orbulina, and Lagena. To the south of Laga Hardim a similar rock exhibits Miliola and Textularia. Several specimens from Burka to Hirna include cylindrical branching structures ( $\frac{1}{2}$ inch across) difficult to determine, and in the microscopic slice one or two specimens of a Dactylopora (?). The sections of the larger structures suggested some resemblance to a sponge; and Dr: G.J. Hinde most kindly undertook a careful examination of

1 'On some Rock-Specimens from Somaliland' Gecl. Mag. 1888, pp. 417, 418. 
the specimens. He reports that there is not a trace of a spicule to be seen, and consequently it cannot be decided whethor tho organism is a calcisponge or not. The fine-grained muddy groundmass, speckled with small crystalline grains of dolomite, contains some minute organisms. The lithological and fossil contents of these limestones make it probable that they are of Cretaceo-Eocene age, or possibly Miocene.'

One limestone 'near the summit of the Pass' from Jigjiga to Abyssinia, found ' in enormous blocks, doubtless fallen from above,' is white or cream-coloured. It is crowded with a gastcropod ( $\frac{1}{2}$ to $\frac{3}{4}$ inch long), doubtless a Turritella, ${ }^{2}$ and in the cut slice a fow fragments of a polyzoan occur. Calcite-crystals line the chambers of the Turritella, and border small fragments and some oolitic grains.

Another limestone, generally fine-grained and muddy, is crowded with organic fragments, which stand out on a weathered surface. The specimen from the hill south of the camp, near Colluby, contains Miliola, Textularia, Calcarina(?), and somo oolitic grains.

The rock at the 'Pass between Colluby and Galimala (?) beneath basalt' furnishes a slightly-brecciated slice, with a cement of clear crystalline dolomite. It encloses brownish oolitic grains and numerous fragments of Lithothamnion, of an cchinoderm-plate or ossicle, and a polyzoan (?).

Chert.-A small flake (probably artificial) of whitish chalcedonic chert was brought from between Jigjiga and Sobolo or Jefa Medr. It is crowded with sponge-spiculos, which are embeddod in pale brownish opaline silica, and are often chalcedonized.

\section{SPECIMENS brodght baCK by LoRd Lovat."}

These were taken chiofly from four localities. The journey was made from Addis Abbeba (about lat. $9^{\circ} \mathrm{N}$.) to Dessieh (about lat. $11^{\circ} \mathrm{N}$.), and the return was by a kind of loop-line to the east.

(1) A hiafedge.-Along the gorge, a section cxposed below the soil ( 6 feet) of the plateau showed a felstone, 10 to 30 feet thick, intercalated between two layers of basalt. Then two successive shoulders, projecting into the valley, consist mainly of a sheet of basalt 200 feet thick. The rock is dark-brown, sometimes 'flaky,' or containing small amygdales or pinhole-cavities filled with a green or brown serpentinous product. A 'weathered rock 40 feet thick' was passed, apparently a gritty tuff, and successive sheets of basalt, one with vesicles partly filled by analcime, one columnar and vesicular, one probably spheroidal. The most interesting specimen is described as 10 feet of ' coal-like rock,' hard and splintery. The fragment is cracked and brittle, and contains a few amygdales. It is a brown glass, with a flow-structure slightly indicated by small

1 See Geol. Mag. 1888, p. 418.

2 See Mayer-Eymar in K. A. von Zittel's 'Beitrïge zur Geol. u. Palæont. der Libyschen Wüste, \&c.' Palæontographica, vol. xxx (1883) pl. xxiii.

${ }^{3}$ I have been unable to identify three localities from which specimens were brought by Lord Lovat, but the rocks, like those of Mount Yoel (Yoil), were mainly basalts. 
belonites, and contains grains of iron-oxide and a few crystals of augite and of felspar, some much corroded, others perfect with albite-twinning. The perlitic cracks in the glass are narrow, and sometimes polarize brightly. The specific gravity (tested on two occasions by a Walker's balance) was found to be between $2 \cdot 33$ and $2 \cdot 38$, the variation being probably due to the cracked and splintery character of the specimen. Thus the rock seems to be an andesitic pitchstone rather than a tachylyte. Other basalts occur (one layer 100 feet thick), then a bed of white quartz-sand, and one of a slightly quartzose red clay, which may be a basaltic tuff or possibly an ordinary sediment.

(2) Mount $\mathrm{Yoel}$ consists largely of igneous rocks, but furnishes one specimen of a white quartz-sand. Decomposed felstones are represented by two rocks at the foot of the mountain (one on the south side). In one fresher porphyrite, just above the plain on the Baramidia (?) side, the groundmass consists mainly of lathshaped plagioclase, with needles and patches of iron-oxide. A black basalt with a ferruginous glass comes from the same side. A red rotten rock may be also either a basalt or a basic ash. A compact, jointed basalt comes from the summit.

(3) Gibbe Hill is formed of volcanic rocks, the specimens being basalts, sometimes glassy, often vesicular or amygdaloidal. One of these, rather rotten, forms a 'bed near the summit.' Another darkred weathered rock becomes disintegrated and reined, with development (in amygdales and veins) of crystals, clear, colourless, often with penetration-twins. These at first sight appear to be cubic, but are really rhombohedral, with low double refraction, and I would refer them to chabazite.

(4) Between Gewaba and Allali(?).-These rocks are compact basalts, microcrystalline (with a second pyroxene or a little altered olivine) or glassy, sometimes spheroidal, as is shown by a flake which has shelled off one specimen. The surface of one fragment is smoothed and ridged, as if worn by blown sand.

(5) Blocks in river-bed, Djemma(?).-One is a dull black rock, compact, but jointed and cracked. The finely-speckled glass contains a few small felspars and augite-crystals, and exhibits perlitic cracks as ill-defined brownish lines, a structure not very frequently found in a magma-basalt. A second block, blackish and compact, but crowded with spherical amygdales, is found to consist of a brown glass, with abundant granular iron-oxide, crossed by perlitic cracks, which are whitish or colourless lines, polarizing brightly. It is doubtless a very basic andesite. A similar rock comes from Gewaba (?), from the lowest exposed bed.

(6) Some water from a hot spring south-west of Addis Abbeba (collected on February 21st, 1899) was brought back. The subjoined analysis was made by Mr. W. L. Alton in the Chemical Laboratory of University College (London), through the kindness of Sir William Ramsay, to both of whom I am greatly indebted :-

Q. J. G. S. No. 234 . 
Total solid residue $=2 \cdot 5806$ grammes per litre.

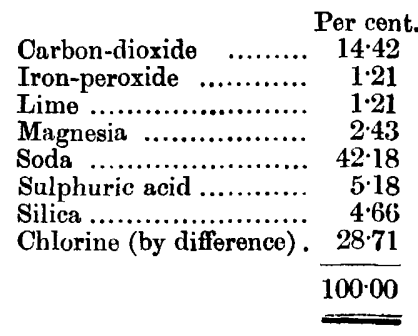

\section{EXPLANATION OF PLATE XXI.}

Map of part of Southern Abyssinia, on the scale of about 70 miles to the inch.

The topography is copied, by kind permission, from the map printed for use at the meeting of the Royal Geographical Society on December 11th, 1899.

The exact position and the area of the outcrops of the rocks can only be roughly indicated, but the general succession of the localities is taken from the dates on the labels accompanying the specimens.

\section{Discussion.}

The Prisident spoke of the interest of the results worked out by the Authoress, and of the clearness with which they had been laid before the meeting by Prof. Bonney. Most of the rocks described appeared to agree remarkably with the other African types usually classed as Tertiary, but a few seemed to suggest those of the Abyssinian plateau associated with the Jurassic limestones of that region. It would be very interesting to know how the widespread Tertiary igneous rocks of Africa were related to, or differed from, those of the earlier geological epochs.

Mr. Prion welcomed the paper as affording still further proof of the wonderful uniformity in type of the more or less recent volcanic rocks of the African continent. Members of the remarkable alkali-rich rock-series, to which the eruptive rocks of the Great RiftValley mainly belonged, were widely distributed over Africa from the island of Pantelleria in the north to Madagascar in the south, as well as in the Canary lslands, the Azores, and other islands off the western coast. This constancy in type was almost sufficient to constitute of Africa an immense petrographical province.

Prof. JUDD congratulated the Authoress on her discovery of the wide range of rocks derived from an alkaline magma. Such rocks, indeed, were now known to be widely distributed, and recent discoveries in Australia and New Zealand had furnished additional evidence on this point.

Prof. Bonner, in reply to the President's question, said that ho believed that the district around and to the north of Addis Abeba formed the southern end of the great Abyssinian plateau, but that no evidence had been furnished as to the geological age of the basalts of which this part was so largely composed. 
Downloaded from http://jgslegacy.lyellcollection.org/ at University of

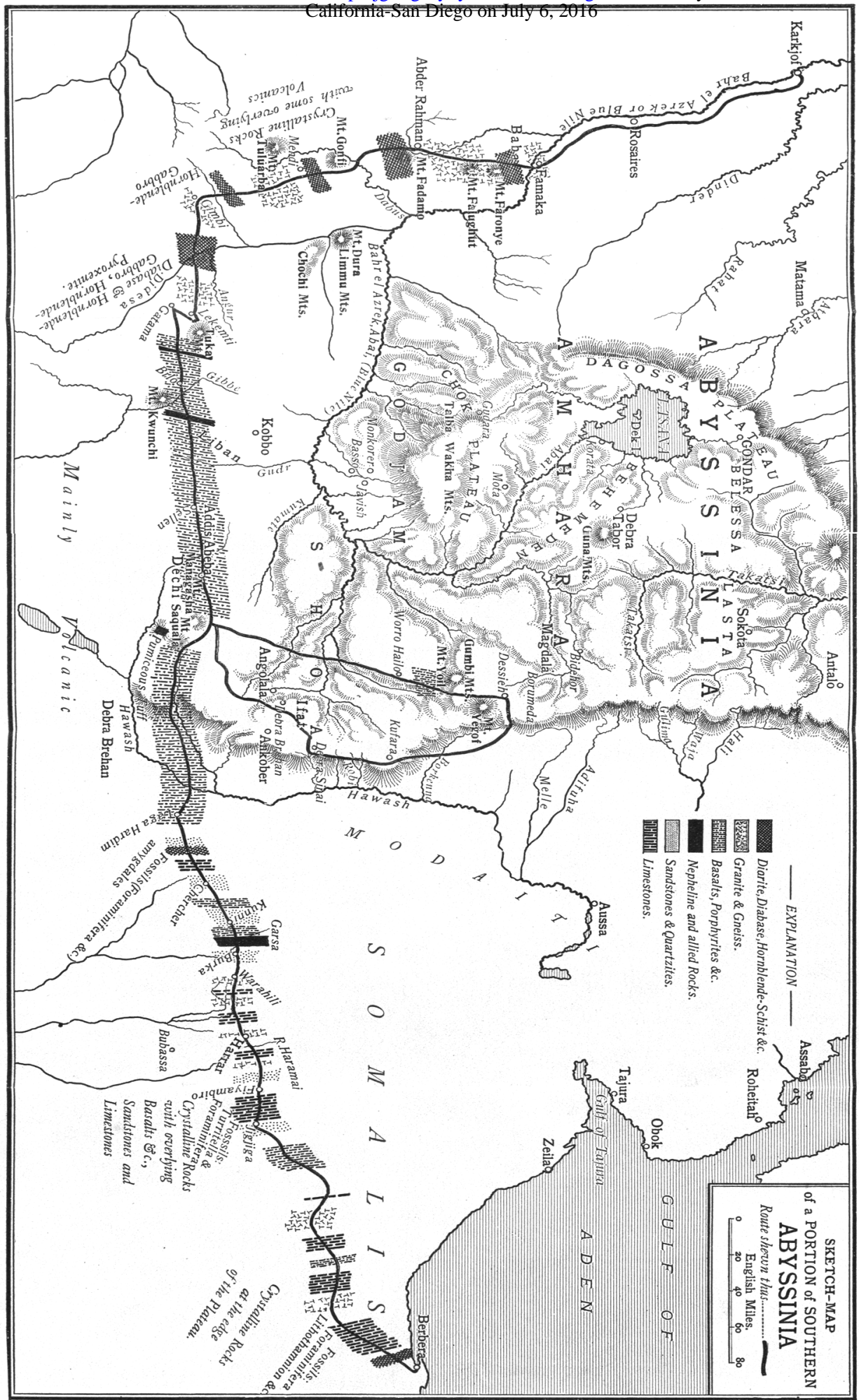

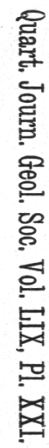

